1

Public Media Initiatives in Bangladesh and South Asia

Politics and Prospects 



\title{
Public Media Initiatives in Bangladesh and South Asia Politics and Prospects
}

\author{
Anis Rahman
}

Simon Fraser University, Canada

\section{Abstract}

The multidimensional growth and transformation of state broadcasters in South Asia indicate that television occupies a major and significant space in the cultural politics of the region. Based on in-depth interviews and secondary data analysis, this paper examines how the state broadcaster in Bangladesh maintains its power in the face of changing media landscapes. Drawing specific attention to Bangladesh Television (BTV), the paper explains how the forthcoming digital switchover may impact the transformation of broadcasting. The paper surveys the consequences of political and commercial influences on state media, and subsequently highlights its efforts for public service. It also shows that non-state actors, such as community radio, transnational multiplatform initiatives, and online blogging are making significant contribution to public media prospects despite their limitations. The paper concludes with brief remarks on required institutional and policy reforms.

Keywords: Bangladesh, South Asia, state broadcaster, Bangladesh Television, digital switchover, community radio, public service media

Anis Rahman, School of Communication, Simon Fraser University, 8888 University Drive, Burnaby, BC V5A 1S6, Canada. Email: abur@sfu.ca

Copyright (C) 2016 (Anis Rahman)

A. Rahman \& G. F. Lowe (Eds.), Public Service Media Initiatives in the Global South

(c) () $\ominus$ Licensed under the Creative Commons Attribution-NonCommercial-NoDerivatives 4.0

International License (CC BY-NC-ND 4.0)

Available at http://monographs.lib.sfu.ca

DOI: 10.21810/sfulibrary.1.7 



\title{
Public Media Initiatives in Bangladesh and South Asia Politics and Prospects
}

\author{
Anis Rahman \\ Simon Fraser University, Canada
}

\section{History and Background \\ of Broadcasting}

Bangladesh is uniquely located between South and Southeast Asia, surrounded by a diverse archaeology of media systems. State broadcasting is a remarkable feature of the region, and has long been foundational to power and prominence. This paper explores how state broadcasters in Bangladesh continue to reorganize in efforts to maintain power in the face of an expanding media market on the one hand, and the growing demands for public service on the other. The paper begins with a terse account of the origins of state-administered broadcasting in South Asia and their ongoing transformation towards public service media organizations. This helps situate state or state-administered broadcasting in Bangladesh into the larger context of public media in South Asia. The paper then briefly outlines the major turning points in the media landscape of Bangladesh. Drawing specific attention to Bangladesh Television (BTV), the paper explains how the forthcoming digital switchover may impact the transformation of broadcasting here, notwithstanding persistent digital divides. The later sections delve deeper into the political and economic issues of state broadcasting, and exemplify efforts to develop public service. We also consider non-state actors, particularly community radio, transnational multiplatform initiatives, and online blogging, as significant contributors to the prospects for public media and public service development, albeit with limitations that are also discussed. The paper concludes with brief remarks on required institutional and policy reforms to achieve a more mature and genuine public service provision in the media landscape of Bangladesh. ${ }^{1}$

\section{State Broadcasting in South Asia}

The grounds for broadcasting in South Asia began in the period of British rule when Bangladesh was administered as East India. In 1937, All India Radio (AIR) was established according to the $\mathrm{BBC}$ model of public service broadcasting, but as a network of stations rather

1 The paper is based on in-depth interviews and secondary data analysis as part of doctoral research in progress at the School of Communication in Simon Fraser University. This paper summarizes findings from interviews with six senior executives and mid-level journalists at Bangladesh Television (BTV) to collect data about news production, organization, and programming strategies. In addition, the author consulted a variety of research reports, statistical sources, and survey data, and incorporated relevant information from research done by other South Asian scholars to enrich the significance of the findings and to contextualize the overall trends. Some discussions have appeared in previous publications (see, Rahman, 2014, 2014 June, and 2016). The author would like to thank Byron Hauck (Simon Fraser University) and Dr. Gregory F. Lowe (University of Tampere) for their suggestions for revision. 
than a centralized service. In the post-Partition era (after 1947)2, AIR as well as Radio Pakistan and later Bangladesh Radio (from 1971), played a central role in shaping national identities and reinterpreting colonial and also pre-colonial histories (Page and Crawley, 2001, p.26). Broadcasting was crucial to government programs related to improvements in general education, health, family planning, agriculture and other development issues across thousands of villages (Agrawal \& Raghaviah, 2006).

Thus, colonial public broadcasting became state broadcasting in postcolonial South Asia. Broadcasting continues to be a powerful national project, although the degree of state control and efforts to develop a public service emphasis do vary from one country to another. Over the decades, extensive efforts have been made to transform India's state broadcasting services, Doordarshan and All India Radio (aka Akashvani), into fully-fledged PSB operators. In the 1990s the Indian government granted autonomy to AIR and Doordarshan to Prasar Bharati by passing the Prashar Bharati Act 1990 and establishing an autonomous body to govern these broadcasters. With the support of the Indian government, Prashar Bharati with its 31 television channels has emerged as one of the largest terrestrial broadcasting networks in the world (Parthasarathi \& Chotani, 2015, p. 66),${ }^{3}$ although the government continues to exercise financial, administrative, and editorial controls (Jain, 2015, p. 149).

Pakistan took a different route and kept the inherited public corporation but operated these channels within a national framework, and later opened new radio stations under this hybrid approach. Within a few decades, the state-owned Pakistan Television (PTV) and Pakistan Broadcast Corporation (PBC) had become a mega-media operator that monopolized the airwaves till 2002, after which the government liberalized the media market. But PTV and PBC still reach the biggest audience terrestrially. ${ }^{4}$

Among the smaller states of South Asia, Nepal and Bhutan followed another path altogether. Nepal has become a pioneer in South Asian community radio. With approximately 350 radio stations, of which most are independent and community owned, community radio is the principal source of news for most people in Nepal (The Conversation, 2015, May 5). After a decade-long assessment, the Japan Overseas Cooperation Agency (JICA) and Radio Nepal are currently formulating policy and legal provisions to transform Radio Nepal into a genuine public service broadcaster (Japan International Cooperation Agency, 2016). For its part, Bhutan's transition to PSB stands out as an example of movement towards independence and democratization of the media is taking place today (Abbott, 2016, p. 19). Bangladesh's Southeast neighbor, Myanmar, has been investing heavily to strengthen its state broadcaster,

${ }^{2}$ At the time of partition in 1947, the AIR network had six stations (Delhi, Mumbai, Calcutta, Chennai, Lucknow, and Tiruchi) in India, while Pakistan got the share of radio stations in Lahore and Peshawar (in West Pakistan) and Dhaka (in East Pakistan, which later became Bangladesh) (All India Radio, 2016a).

${ }^{3}$ Prasar Bharati's television arm, Doordarshan (DD), primarily broadcasts in terrestrial analogue mode and covers about 92 percent of the population and 82 percent of the country's territory (Parthasarathi and Chotani, 2015, p. 66). Akashvani has 415 radio stations across the country, reaching nearly 99.19 percent of the population, and offering programming in 23 languages and 146 dialects (All India Radio, 2016b).

${ }^{4}$ PTV broadcasts two national channels, three regional channels, and one international channel, PTV Global. PBC operates 64 stations broadcast across the country in 22 local and 11 foreign languages. $\mathrm{PBC}$ also owns $22 \mathrm{FM}$-based community-oriented radio stations, and operates nine commercial FM stations (Yusuf, 2013). 
MRTV, as it struggles to maintain a presence in ethnic states. There is a reform proposal to transform MRTV into a public service broadcaster and this is gaining momentum, while a new law will allow community radio to emerge in Myanmar as well (Dragomir, 2016).

This gamut of institutional transformations across a variety of media infrastructures indicate that, first, the resilience of state broadcasters in this region is high and that they are not likely to disappear soon, and second that we see a remarkable trend to transform these institutions and systems into public service organizations. State broadcasters are being forced to adjust to new media environments, creating new opportunities for media reforms and development.

\section{Major Turning Points in the Media Landscape of Bangladesh}

Bangladesh Television (BTV), which is the focal case of this article, launched in 1964 in East Pakistan as a channel of the Pakistan Television Corporation. After Bangladesh independence in 1971, the Awami League government changed the status of BTV from a public corporation into a state broadcaster under the control of the Ministry of Information, thereby fundamentally altering its direction and operation (Shoesmith, Mahmud, \& Reza, 2013, p. 237-238).

Since the 1990s the adoption of free market economic policies and subsequent deregulation and privatization have changed the media landscape across South Asia, effectively ending the absolute domination of state broadcasters in most of these countries. Bangladesh, Nepal, India, Pakistan, and Sri Lanka have all opened their media markets to private ownership and foreign investment. Liberalization has enabled the proliferation of commercial media channels in this region, including Bangladesh. The history of print media is more than two centuries old in this region and its growth over the last 30 years, and its impact on the overall media industry in Bangladesh, is phenomenal. As of late 2014, there were 358 daily newspapers and 82 weekly magazines (Bangladesh Department of Film and Publications, 2014).

The rise of private television was a major turning point for the media landscape in Bangladesh. State-broadcaster Bangladesh Television (BTV) was the dominant medium for televisual news and entertainment for three decades until the advent of cable television in 1992, and subsequent to this the arrival of private television in 1997. In the past decade the number of satellite television channels in Bangladesh has rocketed to 44, although only 26 are currently on air. Growth in the cable and satellite television industries has been driven by massive growth in the telecommunications sector. Giant cell phone companies are competing to invest in media advertising and branding. With more than 110 advertising agencies, the media industry is thriving in Bangladesh, whereas many other industries are facing lay-offs (Rahman, 2016, p. 326).

Since 2008, community radio has emerged in Bangladesh, with high potential for public media intervention. The government has also allowed 28 commercial FM radio channels (12 are active), which rapidly became popular among urban listeners. Once a popular station, Bangladesh Betar, the state broadcaster, is losing audience in both urban and rural areas, despite having 12 regional AM stations and $12 \mathrm{FM}$ stations. While the popularity of radio and cinema has declined, television has consistently ranked as the most popular media in 
contemporary Bangladesh. According to Media and Demographic Surveys (ACNielsen 2015, 2013, 2006), access to television in the urban areas has increased from 69 percent to 96 percent over the last decade. By 2015 access to television surpassed 85 percent nationally (see Figure 1).

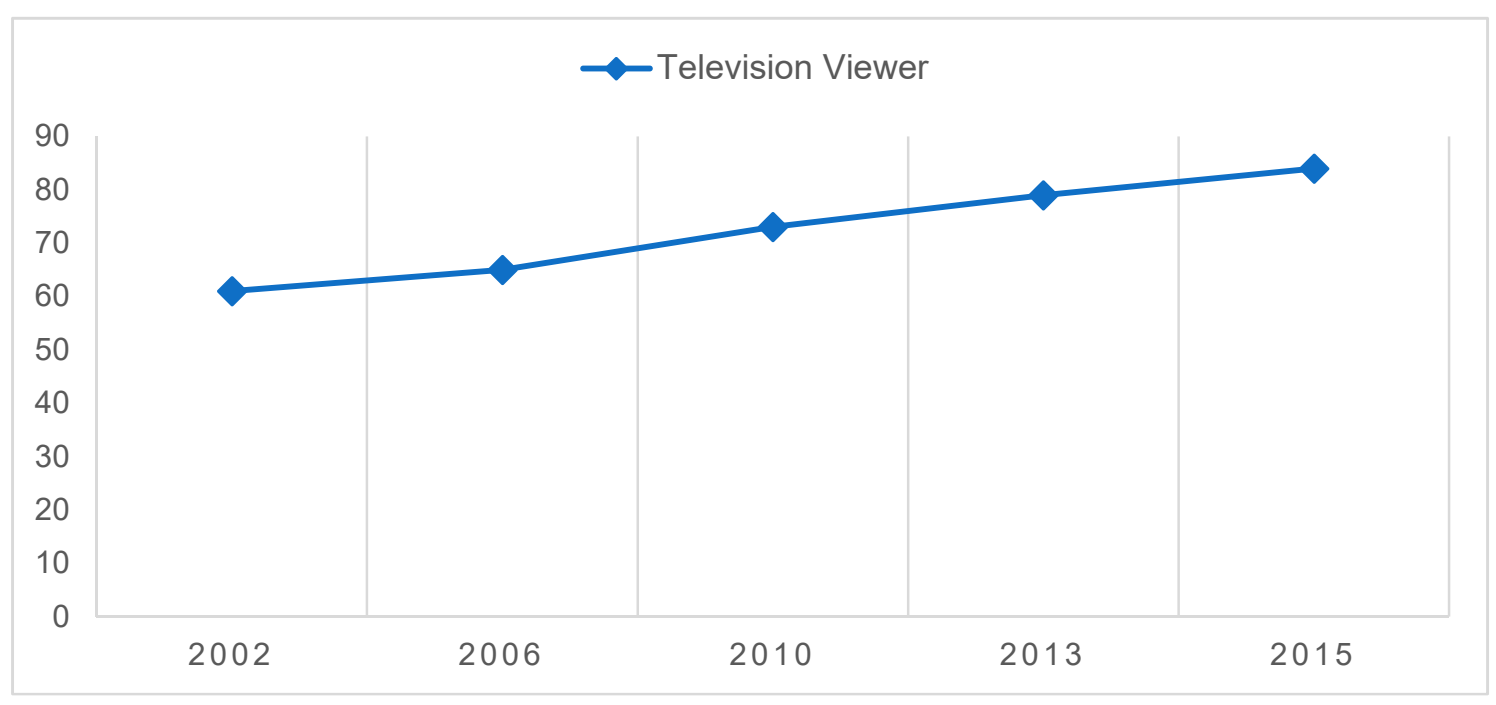

Figure 1. Growth of Access to Television Media in Bangladesh (2002-2015) (sources: ACNielsen, 2015, 2013; 2006).

Consequently, television has become the most popular news source in Bangladesh and is watched by 95 percent of television viewers, followed by drama series (77.6 percent) and Bangla cinema (74 percent) (ACNielsen, 2015). These multidimensional growths and transformations indicate that television occupies a major and significant space in the cultural politics of the nation, not only as a popular medium but also as a powerful institution. It also shows that the state broadcasters are no longer at the center of Bangladeshi cultural space.

\section{Organization and Structure of State-broadcasting in Bangladesh}

State broadcasting in Bangladesh consists of two major platforms, radio and television, which operate under authority of the Ministry of Information. There are also three state-owned and state-managed terrestrial and satellite television channels; Bangladesh Television (BTV), which is terrestrial, BTV World, a satellite channel, and Sangshad TV, the terrestrial Parliament channel. BTV claims a potential coverage of 95 per cent of the territory and is reaching 95 percent of the total population (see, Table 1). BTV boasts 92 percent original content. Employing more than 1568 permanent 1667 temporary staff, BTV is a giant state run organization that, “... aims at the development of the lives of the people and socio-economic progress through its creative programs” (Bangladesh Television, 2016a, 2016b). 
Table 1. Bangladesh Television (BTV) at a glance (2016)

\begin{tabular}{|c|c|}
\hline Scopes & Specifics \\
\hline $\begin{array}{l}\text { Broadcasting } \\
\text { centers }\end{array}$ & 1 Centre (Dhaka), 1 Sub Centers (Chittagong), 14 Relay Stations \\
\hline $\begin{array}{l}\text { Potential } \\
\text { coverage }\end{array}$ & $\begin{array}{l}\text { Terrestrial (BTV): } 95 \% \text { of the territory, } 95 \% \text { of the population } \\
\text { Satellite (BTV World): Asiasat 3S-5, C- BAND transponder, covering } \\
\text { Japan in the far-east New Zealand and Australia in the South Cyprus \& } \\
\text { Egypt in the West and Russia in the North. }\end{array}$ \\
\hline Transmission & Terrestrial: 18 hours per day, Satellite: 24 hours per day \\
\hline Program & $\begin{array}{l}\text { Self-produced: } 92 \% \\
\text { Outsourced: } 8 \%\end{array}$ \\
\hline Total manpower & $\begin{array}{l}\text { Permanent: } 1568 \\
\text { Temporary: } 1667\end{array}$ \\
\hline $\begin{array}{l}\text { Newsroom } \\
\text { personnel }\end{array}$ & Over 100 (including Guest Artists) \\
\hline Major affiliations & $\begin{array}{l}\text { Asia-Pacific Broadcasting Union (ABU) (Administrative Council) } \\
\text { European Broadcasting Union (EBU), Switzerland } \\
\text { Public Media Alliance (PMA), UK }\end{array}$ \\
\hline
\end{tabular}

Sources: Bangladesh Television, 2016a, 2016b.

The institutional authority of state broadcasters in Bangladesh is protected by legal provisions. While BTV claims that it is "accountable to the mass people of Bangladesh," its administrative and financial management is controlled by the government. As per the National Broadcasting Authority Ordinance (1988), Bangladesh Television Authority Act, 2001, and Bangladesh Betar Authority Act, 2001 the topmost executives of BTV and Bangladesh Betar (Director General) are appointed by the Prime Minister. According to Preservation for BTV of Terrestrial Television Broadcast Facilities Act, 2009, only BTV has the right to broadcast terrestrially.

\section{Transition from State-broadcasting to State Media}

\section{From Mono-platform to Multiplatform Mediation}

By the turn of the new millennium, the world's media ecologies were rapidly evolving into a complex site of struggle with multidirectional impacts on public broadcasting, even in the peripheries of economic production. Rapid economic growth in South Asia laid the groundwork for a remarkable expansion of digital media consumption in India and Pakistan (Watts, 2014, p. 293). Bangladesh too, with arguably 55 million Internet users and 132 million people with access to cell phones, has emerged as a thriving hub of new media audience engagement (Bangladesh Telecommunication Regulatory Commission, 2015). The recent trends show that approximately 90 per cent of the Internet users access the Internet through mobile phones, while the rest use broadband Internet from Internet Service Providers (ISP), Public Switched Telephone Networks (PSTN), and private Wi-Fi providers (WiMax). 
As a result of such technological developments and changing media consumption habits, BTV is now reorganizing to be a multiplatform media institution, adapting to the booming digital media landscape. Facing fierce competition from private television channels and online media platforms, BTV has turned global with its satellite channel, online streaming, and IPTV services. In the past decade, Bangladesh Betar reinvented itself with Internet radio streaming services, broadcasting AM and FM stations live through its online portal, apps, as well as a dial-in listening service for the Bangladeshi diaspora.

Such metamorphosis, however, is not exclusive to Bangladesh. It is a global, as well as a regional trend. For instance, the Indian PSB Prasar Bharati is enhancing viewer/listener experience on multiple platforms such as webcasting, podcasting, SMS, and mobile.

\section{From Analog to Digital Broadcasting}

It is noticeable that despite the rapid digital transformation the standard of broadcasting in Bangladesh remains analogue. Bangladesh will miss its initial target for completing the digital switchover in 2016. In fact, the switchover process is yet to begin (Table 2). India has taken the lead in South Asia, completing digital switchover in 2015 and benefiting from it, whereas Pakistan appears to be the least prepared country for this transition (Baig \& Cheema, 2015).

Table 2. Status of the transition to Digital Terrestrial Broadcasting in South Asia

\begin{tabular}{|l|c|c|c|}
\hline Country & DSO date & \multicolumn{1}{c|}{ TV Standard } & Status \\
\hline Bangladesh & 2016 & DVB-T2 & No information \\
\hline Bhutan & 2020 & DVB-T2 & Ongoing \\
\hline India & 2015 & DVB-T & No information \\
\hline Maldives & 2020 & DVB-T2, ISBD-T & No information \\
\hline Nepal & 2017 & DVB-T2 & No information \\
\hline Pakistan & No information & No information & No information \\
\hline Sri Lanka & 2017 & DVB-T2, ISBD-T & \\
\hline
\end{tabular}

Source: International Telecommunication Union (ITU), 2016, as of March 24, 2016

With a view to accelerating the pace of digitization of public broadcasters, the governments of India and Bangladesh have agreed to allow BTV to join Prasar Bharati's DTH (Direct to Home) platform (Prothom Alo, 2015, June 7). Although the economic and technological potential of the digital switchover cannot be overlooked, it is worth asking what benefit it will bring for public media in a country with high income disparity and digital divides? That is impossible to answer, but it is a legitimate concern. 


\section{From Digital Divide to Further Socioeconomic Divides}

There is an interesting debate about the digital divide. At present, fixed-broadband is well beyond the means of most citizens in Bangladesh, especially in rural areas where nearly threequarters of the population live. According to World Bank's most recent study, Bangladesh has the fifth largest offline population in the world, with about 148 million still not connected to the Internet. Going by their figures, only 12 million Bangladeshi's are connected to the Internet today. However, the Bangladesh Telecommunication Regulatory Commission (BTRC) reports that the country's total active Internet subscriptions surpassed 54 million by the end of 2015, of which 51 million were from mobile internet operators (BTRC, 2015; The Daily Star, 2016, January 18).

It is almost shocking how greatly the government (BTRC) data contrasts with the baseline survey. According to ACNeilsen (2015), about 82 percent people (out of 10672 respondents) were not even aware of the Internet. In rural areas this number is greater than 85 percent. As per the survey, the Internet is most known to upper-class urban young residents (lesser than 35 percent) and least known to lower income rural middle-older age people (greater than 92 percent). Indeed, the hype of digital revolution in Bangladesh is greatly exaggerated, at least from the perspectives of age, class, and urban-rural divides. There are certainly further divides in term of gender, literacy, and ethnicity.

In line with the "Digital Bangladesh" project ${ }^{5}$, the government has taken several initiatives to increase the broadband penetration by as much as 50 percent by 2021 by launching the Bangabandhu-1 satellite by 2017 and converting 8,500 post offices into e-commerce centers (The Daily Star, 2016, March 20, and March 19). There is little indication of how these initiatives would make fixed-broadband more affordable for the poorest peasants and working class people, and how this in turn will improve their quality of life. It appears that "Digital Bangladesh" is a discursive construct to promote the interests of private capital in the information sector. One critic has suggested that "Digital Bangladesh as the Bangladeshi version of information society may be seen as a move toward transforming Bangladesh into a neoliberal capitalist society" (Bhuiyan, 2014).

There is no doubt that very soon Bangladesh will overcome the bandwidth supply shortage, but unless the socioeconomic capacity of rural populations improves the cost and distribution of bandwidth will create new forms of digital exclusion for the public in the coming era of digital broadcasting, which is especially problematic for public media initiatives. The digitization of terrestrial broadcasting, similar to the problems faced by Prasar Bharati in India, may not bring benefits for multiple publics because a vast portion of the population are living below the poverty line and will not be able to afford a Set Top-Box (STB) to access digital terrestrial television. ${ }^{6}$ Top private TV channels will be the primary beneficiaries of

${ }^{5}$ As a signatory of the World Summit on the Information Society (WSIS) Declaration, the present Awami League government is actively promoting a variety of "pro-poor" e-enabled public service initiatives (e.g. Union Information and Service Centers, Multipurpose Community Telecenters, Access to Information/A2i program, etc).

${ }^{6}$ The researchers of "Mapping Digital Media in India" project argue that the policy formations that favored digital switchover in India were driven not by a public interest rationale. They wrote, "Policymakers have ignored the fact that few citizens have the requisite mobile handsets and broadband connections; this 
digitalization as they will have more precise access to the middle-class urban and suburban populations who have disposable income and surplus time to consume pay-per-view content. There is no policy direction yet on how the spectrum will be allocated and who will benefit from it, or whether the STBs will be subsidized for those with low income. In sum, the transition from state-broadcasting to public media and the envisioned benefits for the public remain quite uncertain in Bangladesh. Obviously, the digital divide issue is a major challenge for public broadcasting, but it is a low priority compared to other hurdles BTV have faced for decades. It is useful to assess what paralyzes BTV's prospect as a public service media.

\section{Critical Issues of State-broadcasting}

\section{Lack of Autonomy - The Biggest Challenge}

Since the restoration of democracy in 1990 due to a mass uprising against the autocratic ruler, HM Ershad, each successive government has pledged to give autonomy to Betar and BTV. With the restoration of parliamentary democracy in 1991 the issue of 'public broadcasting autonomy' gained momentum that has persisted. The two major political parties (Awami League and Bangladesh Nationalist Party) continued to promise autonomy for BTV and Betar during election campaigns, but when they were in power both parties have failed to demonstrate this commitment in practice. Contrary to their promises, each has continued to use these media as propaganda tools for their own self-interested political gains.

Responding to popular demand, in 1996 the Awami League government constituted a RadioTV Autonomy Commission (aka Asafuddowlah Commission). However, instead of forming a National Broadcasting Commission as recommended, the Awami League government formed two separate authorities under Bangladesh Betar Authority Act, 2001 and Bangladesh Television Authority Act, 2001. The government retained the commanding heights of political control, given that under these draft laws (approved by the cabinet) the government can recruit and terminate executive managers, including the chairperson of both BTV and Betar and can do so without giving any reason. Demand for the autonomy of public broadcasting has thus given rise to grave despair for civil society activists in Bangladesh. ${ }^{7}$

This lack of autonomy is a primary obstacle to BTV functioning as a public service media operator, as the cause of politicization of the administration and polarization of most of the journalistic staff along party lines. BTV lacks credibility due to its structural and on-air bias in favor of ruling parties. ${ }^{8}$ Indeed, news gathering, production, and treatment procedures at BTV manifest a comprehensive and systematic publicity effort focused on the activities of the

suggests the wider digitization of the state broadcaster will benefit only certain sections of society" (Open Society Foundations, 2012, p. 119). In the same vein, Vibodh Parthasarathi and Supriya Chotani (2015, p. 63) argue that the marginal sections of society, for whom Doordarshan is the sole affordable TV outlet, will be the most challenged by this mandatory transition.

${ }^{7}$ For a detailed discussion on this matter, along with a brief political history of television, and policy limitations, see, Shoesmith, Mahmud, \& Reza, 2013; Rahman, 2012 and Khan, 2008.

${ }^{8}$ ACNielsen (2015) survey shows that BTV ranks lower in terms of trustworthiness (26.4 percent) comparing to private TV channels (51 percent) nationally. Another survey run by MRB Bangladesh reports that BTV has very few viewers in the capital city Dhaka (Sharifuzzaman, 2014). 
government, and BTV hardly pretends to camouflage this. Although BTV claims that 78 percent of total programming is about public interest issues, a close examination of the 'Daily News Assignment Schedule' (December, 2013) of BTV News reveals that the majority of news (nearly 52 percent) was pre-determined on the basis of political proximity to the government (e.g. covering activities of ministers, secretariats, bureaucrats, ruling party parliament members, party presidiums, and even BTV high-officials themselves). In most cases the presence of (a) political figure(s) or the reference or request of (b) politically important person(s) has tended to be the key impetus behind the production of news.

Such politicization of news production is not the fault of the Awami League administration alone, but this deformity has been normalized and naturalized in the newsroom through daily routine practice over decades. Consequently, there is no sign of investigative reporting in BTV, except on rare occasions when it comes to 'exposing' maleficence of the opposition party.

\section{Finance - The Usual Suspect}

It is nothing new to observe that state media are becoming increasingly reliant on advertising. Aiming to compete with private TV channels for revenue, BTV uses its superior access to audiences to charge the highest rates for advertising (up to 90,000 BDT=1160 USD per minute) during the news. Until the 1990s, BTV was heavily reliant on importing foreign programs to fill its transmission hours (Riaz, 1993). Although the growth of domestic production houses and the increasing popularity of local artists have enabled BTV to reduce its dependency on foreign programs, the reliance on advertising remains vital. BTV, although fully funded by public sources, profiteers from its self-subordination to the market. This epitomizes a reinforced ideological contradiction facing public media in the neoliberal era (Rahman, 2016, p. 332).

It is ironic that despite high dependency on advertising, BTV has become a losing investment for the government, which is causing it to become more reliant on advertising. About a decade ago (2003-04) BTV was making an annual profit of Tk 520 million, whereas in 2014 it was submerged in losses of nearly Tk 300 million (equivalent to 3.87 million USD). Media columnists suggest that BTV could survive the competition with private television channels if it just kept the news and one talk show in its own control and maintained a good standard and neutrality for the remaining programs (Sharifuzzaman, 2014).

\section{Efforts for Public Service}

Taking into consideration the conditions, one must acknowledge BTV's and Bangladesh Betar's efforts to function as public service providers. These state broadcasters have been particularly recognized for their developmental role by some researchers, notably in public health, family planning, agriculture, and on climate change issues (Hasan \& Baten, 2005; Islam \& Hasan, 2000; Rahman, 2010). BTV's three-decade long contribution to delivering agricultural information to rural farmers through its popular magazine show, Mati O Manush (Soil \& Men), is particularly commendable. Bangladesh Betar offers a variety of agro-based programs that no commercial radio would. 
Both urban and rural television viewers give BTV due credit for its glorious past when it outshined all other forms of entertainment through its ultra-popular drama serials and magazine shows, especially during the weekends. A columnist of Dhaka Tribune writes with nostalgia, "The Friday neighbors would again arrive during nights after the news in Bangla at 80 ' clock. Such social engagement had profoundly influenced us. We may not have realized how BTV had helped us bond with our neighbors and families" (Islam, 2015). Indeed, BTV has a unique past that no other TV channel matches here. Before the dawn of corporate talent shows, BTV opened its doors for hundreds of young talented Bangladeshis with its program Notun Kuri (a national cultural talent hunt show). BTV has always been sincere about telecasting educational programs for children, such as Meena and Sisimpur, award winning drama series that highlight gender inequalities, maternal health issues, and efforts to raise public awareness regarding child marriage. Despite a plethora of TV channels, BTV is still the only channel that has a mandate to broadcast programs for the religious minorities and aboriginal populations. ${ }^{9}$ And BTV is perhaps the closest television channel to Bengali cultural roots as it pays consistent attention to local folk cultural events and indigenous festivities.

These examples signify that BTV is not a basket case or great failure as a public service broadcaster, as some might think and argue. Critics who want to see state broadcasting dead and gone are either unaware of the degrees to which such have sometimes fulfilled an important range of public service roles, and often also overlook the lack of public service offered by private enterprises in the media business.

\section{Alternative Avenues of Public Service}

\section{Community Radio at the Forefront}

Community radio in Bangladesh is perhaps the only type of broadcasting that can claim status as genuine public broadcasting - i.e. not only for the public but also by the public. The community-oriented culture of Bangladesh is favorable for fostering community media. Community Radio (CR) as a "third tier" in Bangladeshi media has the potential to address critical social issues at a community level and provides a platform for marginalized voices (Reza, 2012a). In South Asian context, community radio is not immune to government control, however. ${ }^{10}$ Licensing CR to ruling party members is not uncommon in Bangladesh.

Responding to a decade of advocacy, Community Radio Policy (CR Policy 2008) was first enacted by the Caretaker government in 2007-2008. In 2011, the Sheikh Hasina government authorized 12 community radio stations. By the end of 2013, 125 organizations had applied for permission to operate CR broadcasting. Progress is slow, however. At present there are 17 on the air, broadcasting altogether 125 hours of information programming per day, reaching nearly 5.6 million rural listeners, and employing about a thousand local women and youth [Bangladesh NGOs Network for Radio and Communication (BNNRC), 2016].

\footnotetext{
${ }^{9}$ Interview with Abdullah Al Malun (Producer, News) at BTV Newsroom in Dhaka

10 In Indian case, for instance, the licensing process of community radio is controlled by bureaucratic red-taping. As Pradip Thomas (2014, p. 474) observes that the government in power enjoys ample opportunities to "delay or reject an application if the applicant is not seen to be fit enough."
} 
Community radio brings new hope for regional diversity and may mobilize support for the decentralization of public information in locales. For example, The Guardian (2013, February 22) reported that Radio Mahananda, within its $17 \mathrm{~km}$ radius, "helps farmers share their own crop research with listeners and even invites farmers to participate in studio discussions on capacity development, cultivating improved varieties of seeds, promoting use of organic fertilizers, using less water for irrigation and improving yields". Community radio has large developmental prospects for serving marginalized populations in remote rural habitats, particularly in arid expanses, riverine acres, perennial islands, and coastal areas where state or private media barely operate. A majority of community radio stations are supported by local and international NGOs at the initial stage. While the government has approved 16 more community radio stations, there is no clear roadmap or policy indication as to how these stations will survive once donor support is depleted.

\section{Multiplatform Initiatives: A Proxy PSB in Bangladesh?}

Over the past decade, European donor agencies and media development organizations have recognized the potential offered by multiplatform strategies to deliver public services to broad and targeted audiences not only at home but also in developing regions. For example, with funding from the British government (Department for International Development, DFID) BBC Media Action uses television (e.g. talk show, Bangladesh Sanglap that shows public debates on governance, corruption, and accountability issues; drama series Ujan Ganger Naiya that addresses maternal and newborn health issues), an interactive English learning website (BBC Janala), as well as mobile, social media, and newspaper platforms, to educate and to promote public dialogue in Bangladesh (BBC Media Action, 2012). While the multiplatform media initiatives have gained considerable visibility and popularity in here and elsewhere, their strategies to reach target groups and the impacts of these strategies upon development are not yet reliably understood and often remain unscrutinized.

The Internet has extended opportunities for cyber communities to engage a diverse array of people through blogs in the Bangla language (notably, Somewhereinblog, Sachalayatan, Istishon, and Mukto-mona). There are plenty of examples of bloggers who are the most active community media actors, proactively responding to socio-economic and political issues (Haq, 2013). In times of crises, such as the BDR mutiny in 2009, blogging served as a proxy source of information for many people. During the Shahbag Movement (February 2013 in Dhaka) several thousand protestors gathered to demand the execution of accused war criminals. Unlike the 'Arab Spring', the protestors demanded transparency from the judicial authorities rather than challenging the legitimacy of the political regime. This political protest was sparked and actively organized by a secularist blogger/activist network through Facebook.

The Shahbag Movement provides an example of how social media has presented an unprecedented ability to draw the attention of the media beyond national borders. Thus, online communities can develop a form of alternative citizen journalism through blog sites and social media that is hard for commercial or political powers to control or censor. Although the future potential of the Internet for civic engagement cannot be overlooked, the public service role of blog sites is marginal at best because less than one percent of Bangladesh's Internet users blog (ACNielsen, 2015). 


\section{Assessment and Recommendations}

Due to variations in their complex histories, it is difficult to categorize state broadcasters in South Asia and, equally, to distinguish between what is and is not public service media. It would be naïve to deny to their public service roles, although it is fair and potentially beneficial to be critical of state broadcasting per se. In this region where state broadcasters have characteristics of both state control and public service, state power still dominates over public interests. Independence from political influence is one of the most important prerequisites for public media to function as a service to publics in the South Asian context. In this context, state broadcasting in Bangladesh has to face up to a choice between two fates: either become extinct or become relevant as genuine public service media. The scope and pace of change in media and in these societies is too sweeping to forecast a 'safe' middle ground.

The key findings of this paper suggest several core problems with the existing structures and processes of state broadcasting in Bangladesh, especially, that impede its ability to function as an effective public service media operator. The biggest challenge is BTV's lack of autonomy from state control as a public organization. Worse, BTV is reluctant to gain that needed autonomy from the state out of fear of loosing job security if BTV becomes independent (Rahman, 2014). Bolstered by its terrestrial superiority in reach, BTV is deeply submerged in the culture of political subservience and acquiescence. Unfortunately, there is no easy remedy for such malpractice. This requires a complete overhaul of BTV as a public corporation.

To be a genuine public service media provider, BTV must cut its umbilical cord to the Ministry of Information. That is long overdue. In order to regain its sinking popularity and to earn public trust, BTV must take a critical stance towards the government, whoever is in power, and address social anomalies and state-level aberrations, while dedicating more attention to rural populations and ethnic and religious minorities.

The increasing commercialization of television programs replaces the public value of broadcasting in exchange for market value, which cripples its role for the publics it sets out to serve. Instead of depending more on advertising, BTV and Bangladesh Betar can achieve and maintain financial stability by downsizing its monolithic structure and curtailing further expansion, and by eliminating corruption in purchasing processes by enabling greater transparency. Policy makers could help by levying a television sales tax. In the eventual digital switchover, the government must orientate to serve the public's interests. Stakeholders should agree on a policy to subsidize public access to digital channels at private TV owners' cost, not the other way around. A potential integrated broadcasting policy would address the challenge and opportunities of new media and technological switchovers. A comprehensive policy can be undertaken that will provide guidelines on operational aspects of traditional broadcasting, as well as for new systems of broadcasting such as IP TV, mobile TV, and post-digital switchover audio and video broadcasting (Reza, 2012b).

South Asia has immense potential for the development of decentered and de-institutionalized forms of public media, most specifically through community and folk media. Most ethnicities are deeply rooted in oral cultures, traditions, and festivities. Public media researchers should be aware of inflated promises of Internet-based alternatives to broadcasting. They should also pay more attention to community and folk media with a focus on a culture-centered approach 
to development that highlights dialogue and reflexive participation to create entry points for listening to the voices of marginalized communities (Dutta, 2011). Future researches should also study the overall prospect of media reform in relation to grassroots movements fighting against social inequalities in this region and elsewhere, and the contours of development that are specifically related to the absence or presence of public service media as both an orientation and in operation.

\section{References}

Abbott, S. (2016). Rethinking public service broadcasting's place in international media development. Washington DC: Center for International Media Assistance. Retrieved from http://www.cima.ned.org/wpcontent/uploads/2016/02/CIMA 2016 Public Service Broadcasting.pdf

ACNielsen (2006). Bangladesh mass media and demographic survey 2006. Dhaka: ACNielsen.

ACNielsen (2013). National mass media and demographic survey 2013. Dhaka: ACNielsen.

ACNielsen (2015). National mass media and demographic survey 2015. Dhaka: ACNielsen. Unpublished.

Agrawal, B. C., \& Raghaviah, S. (2006) India: Public service broadcasting and changing perspectives. In Banerjee, I. \& Seneviratne, K. (Eds.). Public service broadcasting in the age of globalization. Singapore: Asian Media Information and Communication Centre.

All India Radio (2016a). Chapter 1: History of All India Radio. In All India Radio Manual, Vol I (pp. 1-13). Retrieved from https://web.archive.org/web/20100917064450/http://allindiaradio.org/Misc/AIRManual1/Chapter1.pdf

All India Radio (2016b). Existing A.I.R. stations. Retrieved from http://allindiaradio.gov.in/wpresources/19LISTOFEXISTINGSTATIONSANDTRANSMITTE $\underline{\text { RS050116.pdf }}$

Baig, A., \& Cheema, U. (2015). Broadcast journalism in Pakistan: A hostage to media economics outlining economic infrastructure of media industry. Centre for Peace and Development Initiatives. Retrieved from http://www.cpdi-pakistan.org/wpcontent/uploads/2015/02/Broadcast-Media-in-Pakistan-Hostage-to-Media-Economy.pdf

Bangladesh Department of Film and Publication (2014). Statistics of listed newspapers and periodicals in the country. Dhaka: Unpublished.

Bangladesh NGOs Network for Radio and Communication (2016). Welcome 17th community radio station in Bangladesh. Retrieved from http://www.bnnrc.net/home/bnnresarabela

Bangladesh Telecommunication Regulatory Commission (2015). Internet subscribers in Bangladesh, December, 2015. Retrieved from http://www.btrc.gov.bd/content/internet-subscribersbangladesh-december-2015

Bangladesh Television (2016a). Welcome message. Retrieved from http://192.185.168.156/ btvgov/

Bangladesh Television (2016b). BTV at a glance. Retrieved from http://192.185.168.156/ btvgov/index.php?option=com content\&view=article\&id=182\&Ite mid $=123$ 
BBC Media Action (2012). Country case study Bangladesh: Support to media where media freedoms and rights are constrained. Retrieved from

http://downloads.bbc.co.uk/mediaaction/pdf/bangladesh.pdf

Bhuiyan, A. J. M. S. A. (2013) 'Digital Bangladesh': Technology, inequality and social change. In Shoesmith, B. \& Genilo, J. W. (Eds.). Bangladesh's changing mediascape: From state control to market forces (pp. 193-215). Bristol: Intellect.

Dragomir, M. (2016, 17 February). Myanmar's government hints about closure of state-run TV are merely an odd hoax. MediaPowerMonitor.com. Retrieved from http://mediapowermonitor.com/content/myanmars-government-hints-about-closure-staterun-tv-are-merely-odd-hoax

Dutta, M. J. (2011). Communicating social change: Structure, culture, and agency. London: Routledge.

Haq, F. (2013) Proposing cyberspace as an alternative media. Social Science Review [The Dhaka University Studies, Part-D], 30(2), 99-106.

Hasan, S., \& Baten, A. (2005). Role of mass media in promotion of family planning in Bangladesh. Journal of Applied Sciences, 5(7), 1158-1162.

International Telecommunication Union (2016). Status of the transition to Digital Terrestrial Television Broadcasting: Summary. Retrieved from http://www.itu.int/en/ITU-D/SpectrumBroadcasting/Pages/DSO/Summary.aspx

Islam, B. (2015, February 27). Congratulations BTV. Dhaka Tribune. Retrieved from http://www.dhakatribune.com/op-ed/2014/dec/29/congratulations-btv

Islam, M. M., \& Hasan A. H. M. S. (2000). Mass media exposure and its impact on family planning in Bangladesh. Journal of Biosocial Science, 32, 513-526.

Jain, S. (2015). India: Multiple media explosions. In K. Nordenstreng \& D. K. Thussu (Eds.), Mapping BRICS media (pp. 145-164). London: Routledge.

Japan International Cooperation Agency (2016). The Project for promoting peace building and democratization through the capacity development of media sector in Nepal. Retrieved from http://www.jica.go.jp/nepal/english/activities/peace.html

Khan, A. (2008). Communication scenes: Bangladesh. In I. Banerjee \& S. Logan (Eds.), Asian communication handbook 2008 (pp. 101-131). Singapore: Asian Media Information and Communication Centre.

Open Society Foundations (2012). Mapping digital media: India. Retrieved from https://www.opensocietyfoundations.org/sites/default/files/mapping-digital-media-india20130326.pdf

Page, D., \& Crawley, W. (2001). Satellites over South Asia: Broadcasting, culture, and the public interest. Thousand Oaks, CA: Sage Publications.

Parthasarathi, V., \& Chotani, S. (2015). The digital switchover of Doordarshan: Intriguing dynamics of policy options. Medijske studije/Media studies, 6, 63-76. Retrieved from http://www.mediastudies.fpzg.hr/images/50022061/ms\%20vol6\%20br12\%20FINAL.pdf

Prothom Alo (2015, June 7). Bangladesh-India joint declaration. Retrieved from http://en.prothomalo.com/bangladesh/news/68785/Bangladesh-India-Joint-Declaration

Rahman, A. (2014). The problems with reimagining public media in the context of Global South. Stream: Culture/Politics/Technology, 6(1), 56-65. Retrieved from http://journals.sfu.ca/stream/index.php/stream/article/viewArticle/88 
Rahman, A. (2014, June). From monopoly to multiplatform? A critical examination of public broadcasting in Bangladesh. Paper presented at the RIPE@2014 Conference: Public Service Media across Boundaries, Tokyo, Japan.

Rahman, A. (2016). Print and electronic media. In A. Riaz \& M. S. Rahman (Eds.), Routledge handbook of contemporary Bangladesh (p. 325-339). London: Routledge.

Rahman, G. (2012). Priority of the media: Profit, politics or the public? Forum, The Daily Star, 6(4).

Rahman, M. (2010). Climate change coverage on the mass media of Bangladesh. Global Media Journal (Indian Edition), 3(1).

Reza, S. M. S. (2012a). From elite perceptions to marginal voices: Community radio in Bangladesh. In Gordon, J. (Ed.). Community radio in the $21^{\text {st }}$ century (pp. 97-113). Oxford: Peter Lang.

Reza, S. M. S. (2012b). Media governance in Bangladesh: Rhetoric and reality of broadcasting policy. Forum, The Daily Star, 6(5).

Riaz, A. (1993). Twenty-three years of programming of Bangladesh Television (1966-89). Asian Journal of Communication, 3(2), 117-127.

Sharifuzzaman (2014, November 11). BTV on a downslide. Prothom Alo. http://en.prothomalo.com/bangladesh/news/56179/BTV-on-a-downslide

Shoesmith, B., Mahmud, S., \& Reza, S. M. S. (2013). A political history of television in Bangladesh. In B. Shoesmith \& J. W. Genilo (Eds.), Bangladesh's changing mediascape: From state control to market forces (pp. 237-255). Bristol: Intellect.

The Conversation (2015, May 5). How the media struggled in Nepal's earthquake rescue. Retrieved from http://theconversation.com/how-the-media-struggled-in-nepals-earthquake-rescue40970

The Daily Star (2016, January 18). Bangladesh has fifth largest offline population globally: WB. Retrieved from http://www.thedailystar.net/business/bangladesh-has-fifth-largest-offlinepopulation-globally-wb-203353

The Daily Star (2016, March 19). Post offices to be turned into e-centres. Retrieved from http://www.thedailystar.net/city/post-offices-be-turned-e-centres-1196221

The Daily Star (2016, March 20). Govt forming a company for country's first satellite. Retrieved from http://www.thedailystar.net/business/govt-forming-company-countrys-first-satellite1196620

The Guardian (2013, February 22). How radio shows for farmers in Bangladesh are boosting crop yields. Retrieved from www.theguardian.com/global-development/2013/feb/22/radiofarmers-bangladesh-crop-yields

Thomas, P. (2014). The ambivalent state and the media in India: Between elite domination and the public interest. International Journal of Communication, 8, 466-482. Retrieved from http://ijoc.org/index.php/ijoc/article/viewFile/2018/1071

Watts, G. (2014). Digital media in Asia: India and Pakistan. In M. Dragomir \& M. Thompson (Eds.), Mapping digital media global findings (pp. 293-300). Open Society Foundations. Retrieved from https://www.opensocietyfoundations.org/sites/default/files/mapping-digital-mediaoverviews-20140828.pdf

Yusuf, H. (2013). Mapping Digital Media: Pakistan. Open Society Foundations. Retrieved from https://www.opensocietyfoundations.org/reports/mapping-digital-media-pakistan 
